\title{
CLASSIFICATION OF OIL-GAS BEARING TARGETS BASED ON THEIR SATURATION FEATURES AND FACIES COMPOSITION APPLYING MATHEMATICAL TECHNIQUES AND INTEGRATED WELL LOGGING DATA
}

\author{
КЛАССИФИКАЦИЯ НЕФТЯНЫХ И ГАЗОВЫХ ОБЪЕКТОВ \\ ПО ПРИЗНАКУ НАСЫЩЕНИЯ И ФАЦИАЛЬНОГО СОСТАВА \\ ОТЛОЖЕНИЙ С ПРИМЕНЕНИЕМ МАТЕМАТИЧЕСКИХ \\ МЕТОДОВ НА БАЗЕ КОМПЛЕКСНЫХ ДАННЫХ ГИС
}

\section{Kifayat A. Kerimova}

\section{К. А. Каримова}

\author{
Azerbaijan State \\ Oil and Industry University, \\ Baku, Republic of Azerbaijan \\ Азербайджанский государственный \\ университет нефти \\ и промышленности, \\ г. Баку, \\ Азербайджанская Республика
}

\begin{abstract}
Большинство нефтегазовых месторождений Азербайджана относятся к терригенным месторождениям. На практике исследования показывают, что большинство терригенных коллекторов неоднородны. Различные слои по своему составу в большинстве случаев различаются по форме, порам, размерам, проницаемости и другим характеристикам. Поэтому такие свойства неоднородности коллекторов были определены или сделаны априори точными. С этой точки зрения оценка условий осаждения терригенного слоя и генезиса отложений, изучение взаимосвязи генезиса пород и нефтегазонасыщенности могут помочь в идентификации новых месторождений.

Целью исследования является разработка классификации перспективных объектов по их насыщенным свойствам и фациальному составу на основе генетической модели, разработанной с использованием количественных характеристик интегрированных данных каротажа скважин и совместной интерпретации результатов «кластерного» анализа коррелированных геофизических параметров.
\end{abstract}

The most of oil-gas fields identified in Azerbaijan are related to terrigeneous deposits. In practice the studies show that most of terrigeneous reservoirs are not homogeneous. Various layers in their composition in most cases are vary by their shape, pores, sizes, permeability and other characteristics. Therefore, such heterogeneous properties of reservoirs have been defined or made accurate a priori. From this point of view, the evaluation of terrigeneous layer sedimentation environment and genesis of sediments, study of interrelation of rocks genesis and oil-gas saturation may assist in identification of new fields.

The study targets to fulfill classification of perspective targets by their saturation properties and facies composition on the basis of genetic model designed by use of quantitative characteristics of integrated well logging data and joint interpretation of «cluster» analysis results of correlated geophysical parameters.

\section{Ключевые слова}

facies composition; flow; saturation; conditional value of resistivity; classification

\section{Key words}

фациальный состав; течение; насыщенность; условное значение удельного сопротивления; классификация 
Classification of survey targets are usually done by various tools. In most cases the number and «weight» of achieved parameters depend on the experience and approach of the researcher. In order to avoid subjectivity factor some mathematical techniques are applied and one of these most widely used techniques is the cluster analysis $[1,2]$.

Thus, the survey targets have been classified for saturation nature and facies composition by use of correlated geophysical parameters $\left(K_{g}, K_{m}\right.$ and $\rho_{A R}$ ) on the basis of performed cluster analysis.

The survey targets in this paper involve Fasila, Upper Kirmaky clay, Upper Kirmaky sand series of Productive Series across AbsheronBalkhanyani zone of uplift studied in sections of well No. 16 of Guneshli field, wells N 4 and $\mathrm{N} 6$ of Chirag field, wells N 4 and N 5 of Azeri field and wells N 3 and N 5 of Kyapaz field. For each well section the correlation coefficient of geophysical parameters has been calculated and conditional value of resistivity of oil-gas bearing layers has been evaluated. Applying cluster analysis and by use of conditional value of resistivity the layers have been evaluated for their saturation properties and facies composition allowing to perform classification of hydrocarbon bearing areas.

According to the Cluster analysis grouping saturation characteristics and facial composition of oil-gas objects

Availability of multiple parameters characterizing the studied target makes impossible the correct resolution of a direct problem. On the other hand, pitfalls of measurements during geophysical survey, variation of geometry and physical peculiarities of the studied target, as well as the presence of multiple factors makes the reverse problem, in other words the interpretation as partially correct. In such cases, very frequent in practice, well logging data interpretation is required by use of mathematical methods [3, 4].

Any feature of survey target can be characterized by several parameters. The survey target described below is characterized by three parameters $[5,6]$.

Classification of survey targets is generally conducted by various methods. At this, the number and «weight» of parameters taken into account mostly depend on the experience and approach method of the researcher [7-9].

To avoid human factor impact the application of some mathematical methods is required and one of these methods is cluster analysis widely used in practice. In this case, to perform the classification we have calculated «proximity» of targets to each other by use of various formulae for evaluation of the distance $[10,11]$.

$$
D=\sum\left[\left(x_{i j}-x_{j i}\right)^{2}\right]^{\frac{1}{2}} .
$$

Based on calculated distances the diagrams of targets proximity are drawn and this makes it possible to analyze and classify them. The survey targets in this paper include Fasila (Break), Upper Kirmaky Clay (UKC), Upper Kirmaky Sand (UKS) of Productive Series (PS) across Absheron-Balkhanyani zone of uplifts [12]. For this, studies covered sections of well N 16 of Guneshli field, wells N 4 and N 6 of Chirag field, wells N 4 and N 5 of Azeri field and wells N 3 and $\mathrm{N} 5$ of Kyapaz field. Interpretation results are given in Table 1. On the basis of correlation of three geophysical parameters $\left(K_{g}, K_{m}\right.$ and $\left.\rho_{A R}\right)$ the saturation characteristics and facies in studied well sections have been analyzed by use of cluster analysis and the following has been derived $[13,14]$.

According to results of cluster analysis for well N 16 of Guneshli field the targets in the studied interval due to their proximity evaluations are divided in two large groups I and II. These major groups are further divided in smaller sub-groups: $\mathrm{I} \rightarrow \mathrm{I}_{1}, \mathrm{I}_{2}, \mathrm{I}_{3}, \mathrm{I}_{4} ; \mathrm{II} \rightarrow \mathrm{II}_{1}, \mathrm{II}_{2}$ (Figure 1).

Classification of these sub-groups have been done through evaluation of facies composition and saturation properties. Studies show that layers included in small sub-groups are layers with similar physical properties. The layers included in the large groups also have similar physical characteristics, however they have definite distances between them.

Layers 3, 8 and 10 in the $\mathrm{I}_{1}$ sub-group are attributed to Fasila suite and characterized as oil reservoirs. Layer 3 is described as flow-featured by its origin and layers 8 and 10 as bar facies.

Layers 2, 9 and 7 in the $\mathrm{I}_{2}$ sub-group are characterized as oil reservoirs (sandy-oily) and bar facies.

Layer 13 in the $\mathrm{I}_{3}$ sub-group is evaluated as water reservoir (water - sandstone) and shallow marine facies.

Layers 1,15 and 16 in the $I_{4}$ sub-group are similar by their physical properties. Layer 15 is featured as water reservoir and layers 1 and 16 as oil reservoirs with all three layers evaluated as the coastal plain by their origin.

Layers 4, 12, 6 and 11 attributed to $\mathrm{II}_{1}-$ subgroup are similar by their characteristics, layers 

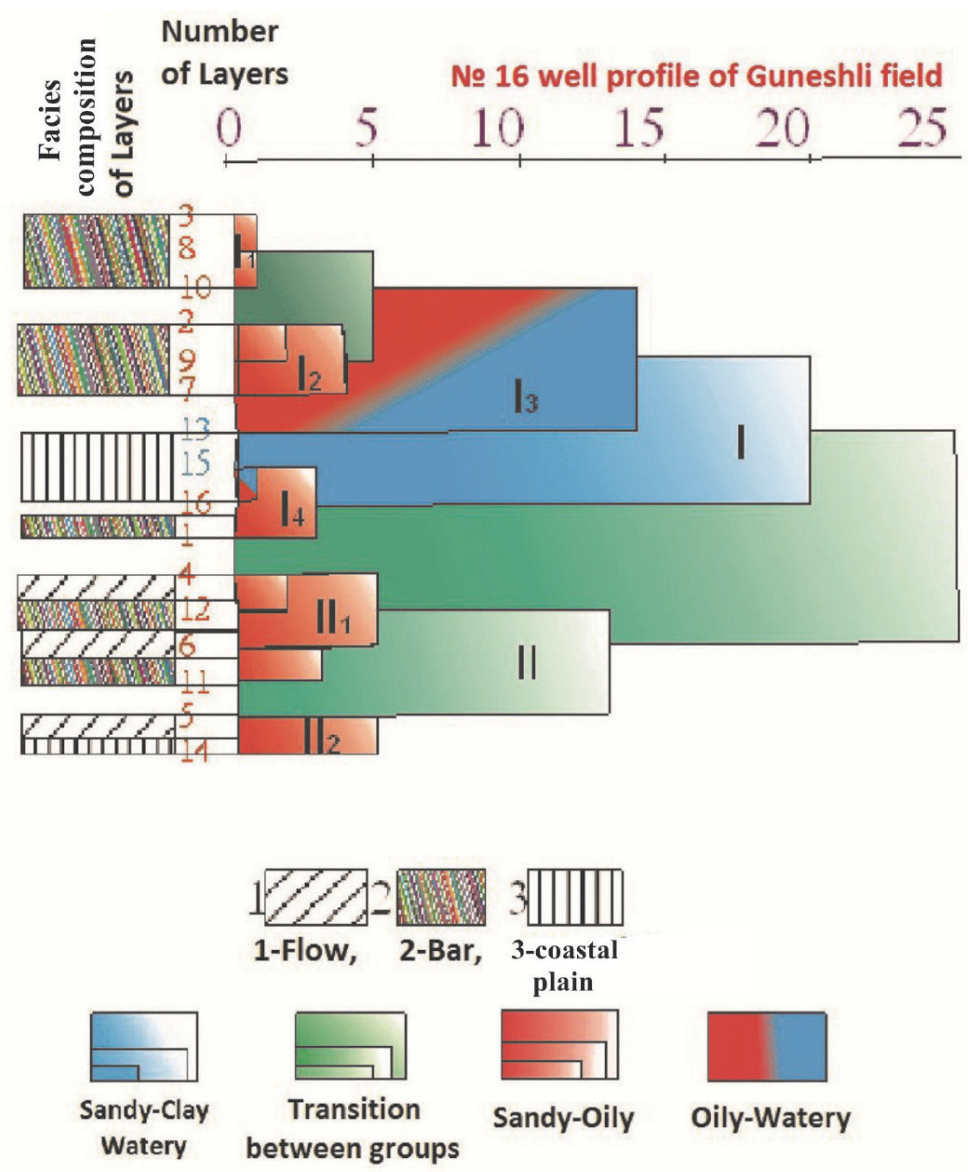

Figure 1. Classification of groups «Fasila» (Break), «UKC» (Upper Kirmaky Clay), «UKS» (Upper Kirmaky Sand) of «PS» (Productive Series) on N 16 well profile of Guneshli field on Claster analysis

4 and 6 are flow-originated facies while layers 11 and 12 are bar facies.

Layers 5 and 14 in the $\mathrm{II}_{2}$ - sub-group are oil reservoirs and distinguish by the proximity distance. Layer 5 is flow-originated while layer 14 is featured by facies of coastal plain origin. Major parameter allowing to evaluate reservoirs by their productivity and water content is resistivity value. It is commonly known that layers saturated by oil and gas have increased resistivity. That is why productive horizons represented by highly porous sandstone can be accurately delineated by these characteristics.

While performing classification for well N 16 of Guneshli field the conditional (boundary) value of resistivity of productive series layers was evaluated as $\rho_{A R}^{\text {cond }} \leq 3.8 \mathrm{Ohm} \bullet \mathrm{m}$. Based on this evaluation the section of well N 16 of Gunashli field for facies composition and layer characteristics is classified as the following.

Layers 13 and 15 attributed to sub-groups $\mathrm{I}_{3}$ and $\mathrm{I}_{4}$ are considered generally as water-reservoirs on the basis of conditional value of resistivity and from the point of view of facies composi- tion they are evaluated as coastal plain origin. According to studies both layers are attributed to Fasila suite and buried at 3619-3631 and 3646-3650 $\mathrm{m}$ depth intervals respectively.

Other layers included into the I large group on the basis of conditional value of resistivity were evaluated mainly as oil reservoirs and bar facies.

$\mathrm{II}_{1}$ and $\mathrm{II}_{2}$ sub-groups included in the II large group were evaluated as oil reservoirs and due to facies composition as alternation of flow and bar facies.

A definite regularity is observed in this classification evidencing the accuracy of classification done by use of cluster analysis.

Similar studies covered well sections of wells 4 and 6 of Chirag field, wells N 4 and N 5 of Azeri field and wells 3 and 5 of Kyapaz field. Layers in these well sections have been classified by the proximity of targets, saturation properties and facies composition.

According to cluster analysis done for section of well N 4 of Chirag field the survey targets by their proximity are divided into the I and II large groups. These groups are divided further into 

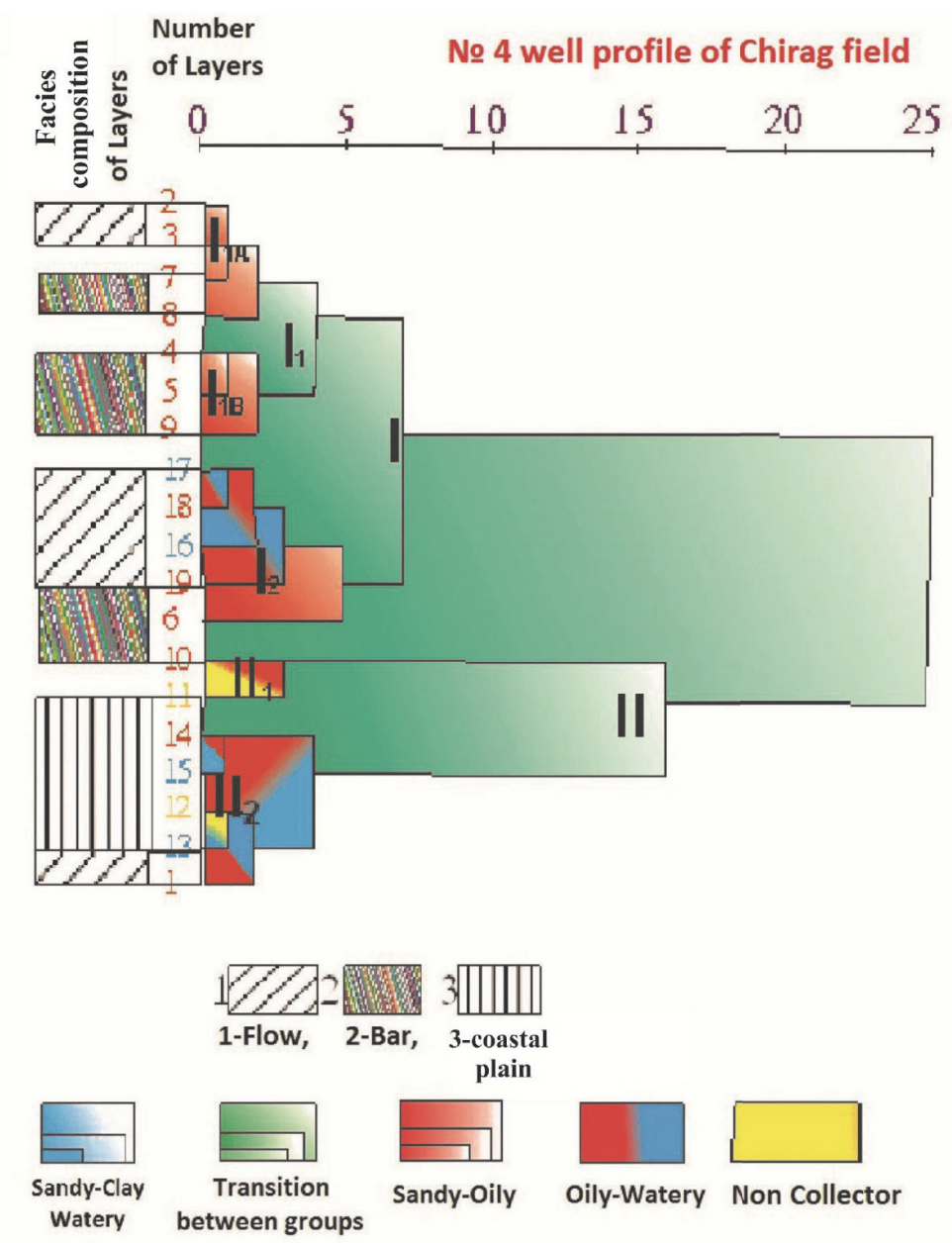

Figure 2. Classification of groups «Fasila» (Break), «UKC»

(Upper Kirmaky Clay), «UKS» (Upper Kirmaky Sand) of «PS»

(Productive Series) on N 4 well profile of Chirag field on Claster analysis

the following sub-groups: $\mathrm{I} \rightarrow \mathrm{I}_{1}\left(\mathrm{I}_{1 \mathrm{~A}}, \mathrm{I}_{1 \mathrm{~B}}\right)$; $\mathrm{II} \rightarrow \mathrm{II}_{1}$ and $\mathrm{II}_{2}$ (Figure 2).

Layers 2, 3, 7 and 8 included in the $\mathrm{I}_{1 \mathrm{~A}}$ subgroup are evaluated as oil reservoirs, layers 2 and 3 are of flow origin while layers 7 and 8 are bar facies.

Layers 4, 5 and 9 included in the $\mathrm{I}_{1 \mathrm{~B}}$ subgroup are oil reservoirs and bar facies.

Layers $17,18,16,19$, and 6 included in the $\mathrm{I}_{2}$ sub-group consist of alternation of oil and water reservoirs, layers 17, 18, 16, 19 are evaluated as flow facies while layer 6 as bar facies.

Layers 10 and 11 in the $\mathrm{II}_{1}$ sub-group are distinguished by their saturation properties and origin. Layer 10 is oil reservoir and consists of bar facies while layer 11 is not a reservoir and coastal plain originated.

Layers $14,15,12,13$ and 1 in the $\mathrm{II}_{2}$ subgroup are layers with distinguishing features. Layers 1 and 14 are oil reservoirs, layers 13 and 15 are water reservoirs and layer 12 is non-reservoir. Due to facies composition, layer 1 consists of flow facies, layers 14, 15, 12 and 13 are con- sidered as coastal plain. It can be seen from the analysis that layers in the II group are grouped on the basis of diversity of features.

Conditional value of resistivity of productive layers according to classification done for well $\mathrm{N} 4$ of Chirag field has been evaluated as $\rho_{A R}^{c o n d} \leq 4 \mathrm{Ohm} \cdot \mathrm{m}$. According to this evaluation, the section of well N4 of Chirag field has been described as the following [15].

Layers 13 and 15 in the $\mathrm{II}_{2}$ sub-group are also water reservoirs with facies of coastal plain origin. These are the layers of Upper Kirmaky Sand series and are buried within 3342-3344 $\mathrm{m}$ and 3356-3358 m intervals. Layers 11 and 12 are nonreservoirs with facies of coastal plain origin.

Layers in the sub-groups $\mathrm{I}_{2 \mathrm{~A}}$ and $\mathrm{I}_{2 \mathrm{~B}}$ are oil reservoirs and consist of alternation of flow facies and bar facies. Some regularity is observed in this classification also.

To identify oil reservoirs and water reservoirs in the section of well N 4 of Azeri field the conditional value of resistivity of productive layers was evaluated as $\rho_{A R}^{\text {cond }} \leq 4.5 \mathrm{Ohm} \cdot \mathrm{m}$. Layers 
in the section of well N 4 of Azeri field were classified as the following.

On the basis of cluster analysis done for well N4 of Azeri field the section is divided into I and II large groups by the proximity of targets. These large groups are divided further into small subgroups (Figure 3).

$\mathrm{I} \rightarrow \mathrm{I}_{1}, \mathrm{I}_{2} ; \mathrm{II} \rightarrow \mathrm{II}_{1}, \mathrm{II}_{2}, \mathrm{II}_{3}, \mathrm{II}_{4}$

Layers 10 and 11 in the $I_{1}$ sub-group are oil reservoirs and consist of bar facies.

Layers $9,16,18$ in the $I_{2}$ are oil reservoirs (layers 9 and 16) and water reservoirs (layer 18) with layer 9 consisting of bar facies and layers 16 and 18 are of flow originated facies.

Layers $14,15,13,12$ in the $\mathrm{II}_{1}$ sub-group consist of oil reservoirs $(14,13,12)$ and water reser- voir (15) and characterized as flow originated facies.

Layers 4 and 5 included in $\mathrm{II}_{2}$ sub-group are almost similar by their physical properties and evaluated as oil reservoirs with facies of coastal plain features.

Layers 2 and 7 making up the $\mathrm{II}_{3}$ sub-group are also similar by their physical characteristics and evaluated as oil reservoirs with layer 7 considered as bar facies and layer 2 as coastal plain facies.

Layers $6,8,17,3$ and 1 of the $\mathrm{II}_{4}$ sub-group are characterized as oil reservoirs, layers 1 and 3 are evaluated as coastal plain, layers 6 and 8 as bar facies and layer 17 as flow-originated facies.
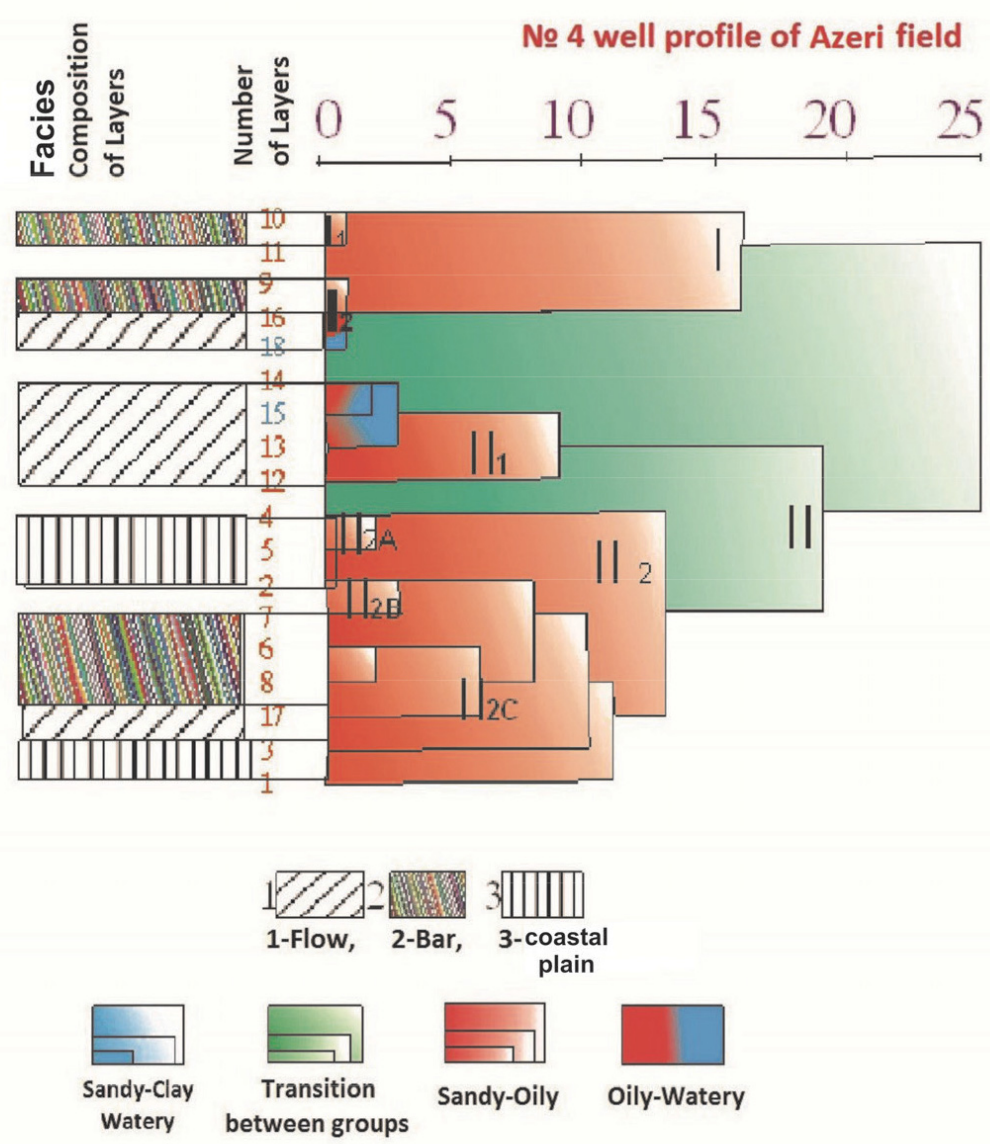

Figure 3. Classification of groups «Fasila» (Break), «UKC»

(Upper Kirmaky Clay), «UKS» (Upper Kirmaky Sand) of «PS»

(Productive Series) on N 4 well profile of Azeri field on Claster analysis

Cluster analysis applied to section of well $\mathrm{N}$ 5 of Kyapaz field displayed that the targets in the section by their proximity are divided into the following groups: $\mathrm{I}$ and $\mathrm{II} \mathrm{II}_{1}, \mathrm{II}_{2}\left(\mathrm{II}_{2 \mathrm{~A}}, \mathrm{II}_{2 \mathrm{~B}}\right)$ (Figure 4).

Layers $9,10,13$ and 14 in the I group are water reservoirs and were evaluated as coastal marine facies.
Layers 2, 6 and 5 are considered as oil reservoirs with layer 2 evaluated as bar facies, layers 5 and 6 as flow-originated facies.

Layers $1,7,3$, and 12 in the $\mathrm{II}_{2 \mathrm{~A}}$ sub-group consists of alternation of oil reservoirs $(7,3)$ and water reservoirs $(1,12)$ while layers 1 and 3 are bar facies and layers 7 and 12 are flow-originated facies. 

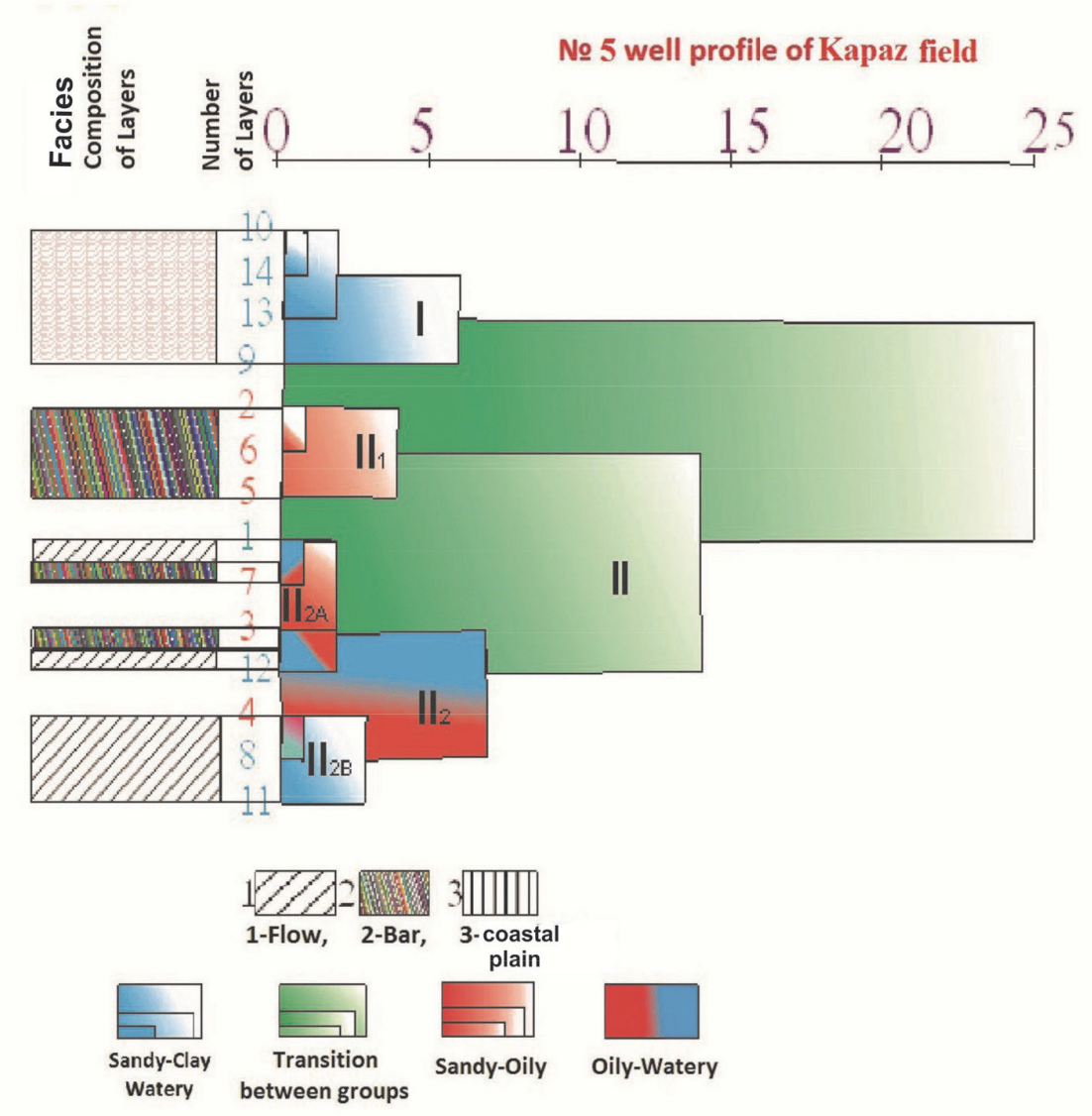

Figure 4. Classification of groups «Fasila» (Break), «UKC»

(Upper Kirmaky Clay), «UKS» (Upper Kirmaky Sand) of «PS» (Productive Series) on N 5 well profile of Kyapaz field based on Claster analysis

Of layers 4,8 and 11 of the $\mathrm{II}_{2 \mathrm{~B}}$ sub-group the layers 8 and 11 by their saturation characteristics were evaluated as water reservoirs, layer 4 as oil reservoir, layers 4 and 11 are evaluated as floworiginated and layer 8 as coastal plain facies.

Conditional value of resistivity of productive layers in section of well N 5 in Kyapaz field constitutes $\rho_{A R}^{\text {cond }} \leq 3 \mathrm{Ohm} \cdot \mathrm{m}$. Based on this evaluation the facies and layer characteristics in section of well N 5 in Kyapaz field are classified as the following.

Layers 9, 10, 13 and 14 in the I group are water reservoirs and evaluated as coastal marine facies.

Layers 1, 12, 8 and 11 in the II group are evaluated as water reservoirs and as flow-originated facies. Of these layers the layers 1 and 8 are attributed to Fasila suite and buried at 3617-3622 $\mathrm{m}$ and 3771-3774 $\mathrm{m}$ depth intervals, layers 11 and 12 are attributed to Upper Kirmaky Sand suite and buried at 3937-3939 $\mathrm{m}$ and 3941-3950 $\mathrm{m}$ depth intervals respectively. Despite that these layers are attributed to various layer groups and buried at various intervals, as a result of cluster analysis they have been included in a same group. This evidences the reliability of performed analysis. Similar to other well sections some regularity is observed in this well section also.

Thus, to classify survey targets by saturation nature and facies composition the correlation coefficient of geophysical parameters have been calculated for each well section on the basis of three correlated geophysical parameters $\left(K_{g}, K_{m}\right.$ and $\rho_{A R}$ ) applying cluster analysis. Conditional value of resistivity for well section have been defined. Cluster analysis by use of conditional value of resistivity allowed to perform classification of layers by their saturation nature and facies composition.

\section{Conclusions}

On the basis of values of $K_{g}, K_{m}$ and $\rho_{A R}$ parameters by use of «cluster» analysis the studied targets are classified due to their saturation properties; As a result of joint interpretation of genetic model and «cluster» analysis the perspective targets have been grouped due to their saturation and facies composition, and the regularity between saturation properties and facies of layers has been defined. 
As a result of investigation, grouping of saturation feature and facial content on the base of cluster analysis (according to comparable (cor-

\section{REFERENCES}

1. Scherer M.S., Goldberg K., Bardola T. Facies Architecture and Sequence Stratigraphy of an Early PostRift Fluvial Succession, Aptian Barbalha Formation, Araripe Basin, Northeastern Brazil. Sedimentary Geology, 2015, Vol. 322, pp. 43-62.

2. Fadela A., Zigaite Z., Bloma H., Perez-Huertac A., Jeffrised T. e.a. Palaeoenvironmental Signatures Revealed from Rare Earth Element (REE) Compositions of Vertebrate Micro Remains of the Vesak Bone Bed (Homerian, Wenlock), Saaremaa Island, Estonia. Estonian Journal of Earth Science, 2015, Vol. 64, pp. 36-41.

3. Kerimova K.A. Integrated Interpretation of Well Data. Baku, 2014. 86 p.

4. Erarslan C., Orgün Y. Mineralogical and Geochemical Characterization of the Saray and Pinarhisar Coals, Northwest Thrace Basin. International Journal of Coal Geology, 2017, Vol. 173, pp. 9-25.

5. Kocharli Sh.S. Problemnyye voprosy neftegazovoy geologii Azerbaydzhana [Problematic Issues of Oil and Gas Geology of Azerbaijan]. Baku, 2015. 278 p. [in Russian].

6. Mamedov P.Z. O prichinakh bystrogo progibaniya zemnoy kory v Yuzhno-Kaspiyskoy vpadine [On the Causes of Rapid Deflection of the Earth's Crust in the South Caspian Depression]. Azerbaydzhanskoye neftyanoye khozyaystvo - Azerbaijan Oil Industry, 2008, No. 1, pp. 8-19. [in Russian].

7. Attia I., Helal I., El Dakhakhny A., Aly S.A. Using Sequence Stratigraphic Approaches in a Highly Tectonic Area: Case Study - Nubia (A) Sandstone in Southwestern Gulf of Suez, Egypt. Journal of African Earth Science, 2017, Vol. 136, pp. 10-21.

8. Pereira P., Brevik E., Munoz-Rojas M., Miller B. Soil Mapping and Process Modeling for Sustainable Land Use Management. Elsevier, 2017. 398 p.

9. Mineral Deposits and Metallogeny of Fennoscandia. P. Eilu (ed.) Geological Survey of Finland, 2012, Vol. 53, $401 \mathrm{p}$.

10. Kerimova K.A. Analysis of Reservoir Properties and Genesis of Sedimentary Rocks of South Caspian Basin. Scientific Newsletter «Karotajnik», 2009, No. 11 (188), pp. 38-47.

11. Kerimova K.A. Genetic Model of Sedimentary Rocks on the Basis of Integrated Geophysical Data Acquired in the South Caspian Basin: Thesis. Baku, 2011. 181 p.

12. Seidov V.M. Sostavleniye i analiz sedimentatsionnykh modeley protsessa osadkonakopleniya na osnove dannykh krivykh karotazha [The Compilation and Analysis of Sedimentation Models of Teh Sedimentation Process Based on the Data of the Logging Curves]. Izvestiya vysshikh tekhnicheskikh uchebnykh zavedeniy Azerbaydzhana - Transactions of Azerbaijan Institutes of Technology, 2017, No. 5 (109), pp. 23-33. [in Russian].

13. Mammadov P.Z, Kerimova K.A, Mammadova L.P. Study of Facies Composition of the Early Pliocene (Productive Series) Deposits of South Caspian Basin on the related) value of three geophysical parametres) is useful for classification of oil-gas areas and increasing geological useful of GEW.

Basis of Well Logging Data. Geophysics News in Azerbaijan, 2015, No. 3-4, pp. 3-7.

14. Shilov G.Y., Jafarov I.S. Genetic Models of Sedi mentary and Volcanogenic Rocks and Facies Interpretation Techniques on the Basis of Geological-Geophysical Data. 2001, 393 p.

15. Kerimova K.A., Seidov V.M., Mahmudov A.A., Alibekova E.T., Pashayeva Sh.V. Litofatsial'naya korrelyatsiya produktivnoy tolshchi vdol' regional'nogo seysmicheskogo profilya $\mathrm{v}$ peredelakh khronostratigraficheskikh granits Yuzhno-Kaspiyskoy vpadiny v ApsheronPribalkhanskoy tektonicheskoy zone [Litafacial Correlation of the Productive Strata Along the Regional Seismic Profile within the Chronostratigraphic Boundaries of the SouthCaspian Basin in the Absheron-Pribalkhan Tectonic Zone]. Azerbaydzhanskoye neftyanoye khozyaystvo - Azerbaijan Oil Industry, 2015, No 3, pp. 10-14. [in Russian].

\section{СПИСОК ИСПОЛЬЗУЕМЫХ ИСТОЧНИКОВ}

1. Scherer M.S., Goldberg K., Bardola T. Facies Architecture and Sequence Stratigraphy of an Early PostRift Fluvial Succession, Aptian Barbalha Formation, Araripe Basin, Northeastern Brazil // Sedimentary Geology. 2015. Vol. 322. P. 43-62.

2. Fadela A., Zigaite Z., Bloma H., Perez-Huertac A., Jeffrised T. e.a. Palaeoenvironmental Signatures Revealed from Rare Earth Element (REE) Compositions of Vertebrate Micro Remains of the Vesak Bone Bed (Homerian, Wenlock), Saaremaa Island, Estonia // Estonian Journal of Earth Science. 2015. Vol. 64. P. 36-41.

3. Kerimova K.A. Integrated Interpretation of Well Data. Baku, 2014. 86 p.

4. Erarslan C., Orgün Y. Mineralogical and Geochemical Characterization of the Saray and Pinarhisar Coals, Northwest Thrace Basin // International Journal of Coal Geology. 2017. Vol. 173. P. 9-25.

5. Кочарли Ш.С. Проблемные вопросы нефтегазовой геологии Азербайджана. Баку, 2015. 278 с.

6. Мамедов П.З. О причинах быстрого прогибания земной коры в Южно-Каспийской впадине // Азербайджанское нефтяное хозяйство. 2008. № 1. С. 8-19.

7. Attia I., Helal I., El Dakhakhny A., Aly S.A. Using Sequence Stratigraphic Approaches in a Highly Tectonic Area: Case Study — Nubia (A) Sandstone in Southwestern Gulf of Suez, Egypt // Journal of African Earth Science. 2017. Vol. 136. P. 10-21.

8. Pereira P., Brevik E., Munoz-Rojas M., Miller B. Soil Mapping and Process Modeling for Sustainable Land Use Management. Elsevier, 2017. 398 p.

9. Mineral Deposits and Metallogeny of Fennoscandia // Geological Survey of Finland. 2012. Vol. 53. 401 p.

10. Керимова К.А. Анализ коллекторских свойств и генезиса осадочных пород Южно-Каспийской впадины // Научный вестник «Каротажник». 2009. № 11 (188). C. 38-47. 
11. Kerimova K.A. Genetic Model of Sedimentary Rocks on the Basis of Integrated Geophysical Data Acquired in the South Caspian Basin: Thesis. Baku, 2011. 181 p.

12. Сеидов В.М. Составление и анализ седиментационных моделей процесса осаждения на основе кривых каротажа // Известия высших технических учебных заведений Азербайджана. 2017. № 5 (109). С. 23-33.

13. Mammadov P.Z, Kerimova K.A, Mammadova L.P. Study of Facies Composition of the Early Pliocene (Productive Series) Deposits of South Caspian Basin on the Basis of Well Logging Data // Geophysics News in Azerbaijan. 2015. No. 3-4. C. 3-7.

\section{ABOUT THE AUTHOR}

ОБ АВТОРЕ

Kifayat A. Kerimova, Candidate of Geological and Mineralogical Sciences, Assistant Professor of Geophysics Department, Azerbaijan State Oil and Industry University, Baku, Republic of Azerbaijan

Керимова Кифаят Аладдин кызы, канд. геол.-минерал. наук, доцент кафедры «Геофизика», Азербайджанский государственный университет нефти и промышленности, г. Баку, Азербайджанская Республика

e-mail:kifageo.com@rambler.ru
14. Shilov G.Y., Jafarov I.S. Genetic Models of Sedimentary and Volcanogenic Rocks and Facies Interpretation Techniques on the Basis of Geological-Geophysical Data. 2001. $393 \mathrm{p}$.

15. Керимова К.А., Сеидов В.М., Махмудов А.А., Алибекова Е.Т., Пашаева Ш.В. Литофациональная коррекция продуктивной толщи вдоль регионального сейсмического профиля в переделах хроностратиграфических границ Южно-Каспийской впадины в АпшеронПрибалханской тектонической зоне // Азербайджанское нефтяное хозяйство. 2015. № 3. С. 10-14. 